\title{
First report of Teratosphaeria pseudoeucalypti in Uruguay
}

\author{
S. Soria • R. Alonso • L. Bettucci • S. Lupo
}

Received: 11 March 2014 / Accepted: 21 August 2014 / Published online: 9 September 2014

(C) Australasian Plant Pathology Society Inc. 2014

\begin{abstract}
Teratosphaeria pseudoeucalypti was found causing leaf blight disease on Eucalyptus globulus and E. maidenii in forestry plantations in Uruguay. The pathogen was identified by morphological characteristics and sequence analysis of the ITS-2, part of the $\beta$ T and part of the EF-1 $\alpha$ DNA.
\end{abstract}

Keywords Eucalyptus plantations · Leaf spot · Phylogeny · Teratosphaeria $\cdot$ South America

In Uruguay, after the approval of the forestry law in 1987, the forested area with exotic species increased from 25.000 to 990.030 ha in 2012. Eucalyptus is the most widely planted genus, covering 726.323 ha. The main planted species of Eucalyptus are: E. globulus (51 \%), E. grandis $(34 \%)$ and E. dunnii $(11 \%)$ (MGAP 2013).

Plantations for industrial purpose with short cycle, high density and uniform genotypes, could favor the development of pathogens. Mycosphaerella Leaf Disease (MLD) caused by species of Mycosphaerella and Teratosphaeria represent one of the major diseases affecting Eucalyptus spp. worldwide. Many species of Mycosphaerella and Teratosphaeria affecting eucalypt have been reported in Uruguay (Lupo et al. 2008).

S. Soria $(\bowtie) \cdot$ R. Alonso $\cdot$ L. Bettucci $\cdot$ S. Lupo Laboratorio de Micología, Facultad de Ciencias-Facultad de Ingeniería, Universidad de la República,

Julio Herrera y Reissig 565, Montevideo, Uruguay

e-mail: soria.silvina@gmail.com
However, it was only since 2007, when T. nubilosa was first recorded (Pérez et al. 2009) that severe damage began to appear mainly in E. globulus plantations. T. nubilosa has become the main phytosanitary problem in E. globulus stands, producing significant defoliation and tree death.

Teratosphaeria pseudoeucalypti was first discovered in Australia on Eucalyptus sp. and E. grandis $\mathrm{x}$ E. camaldulensis (Andjic et al. 2010). The main symptom associated with T. pseudoeucalypti are subcircular to irregular leaf spots, initially pale green, turning chlorotic before becoming necrotic, light to medium brown, with red-purple margin on the upper and lower surface. Although this symptom can be confused with that produced by Teratosphaeria eucalypti, analysis of different regions of DNA showed that it was caused by a new species, recorded to date only in Australia (Andjic et al. 2010).

In the last 2 years, a new leaf blight disease has been observed in Uruguay on both juvenile and adult leaves of several Eucalyptus species. The symptom observed were yellow necrotic leaf spots turning necrotic and dark brown with chlorotic margins (Fig. 1). The aim of this study was to identify the foliar pathogen causing this disease using multi gene phylogeny.

Juvenile leaves with leaf blotches were collected from E. globulus and E. maidenii plantations at the south east region of Uruguay. The lower surface of blotches was covered by dark pycnidia. Monosporic isolates were performed from conidia produced on pycnidia and grown onto $2 \%$ Malt Extract Agar (MEA) at $25{ }^{\circ} \mathrm{C}$. Colonies reached 10-20 $\mathrm{mm}$ after 4 weeks on MEA in the dark. All isolates are 


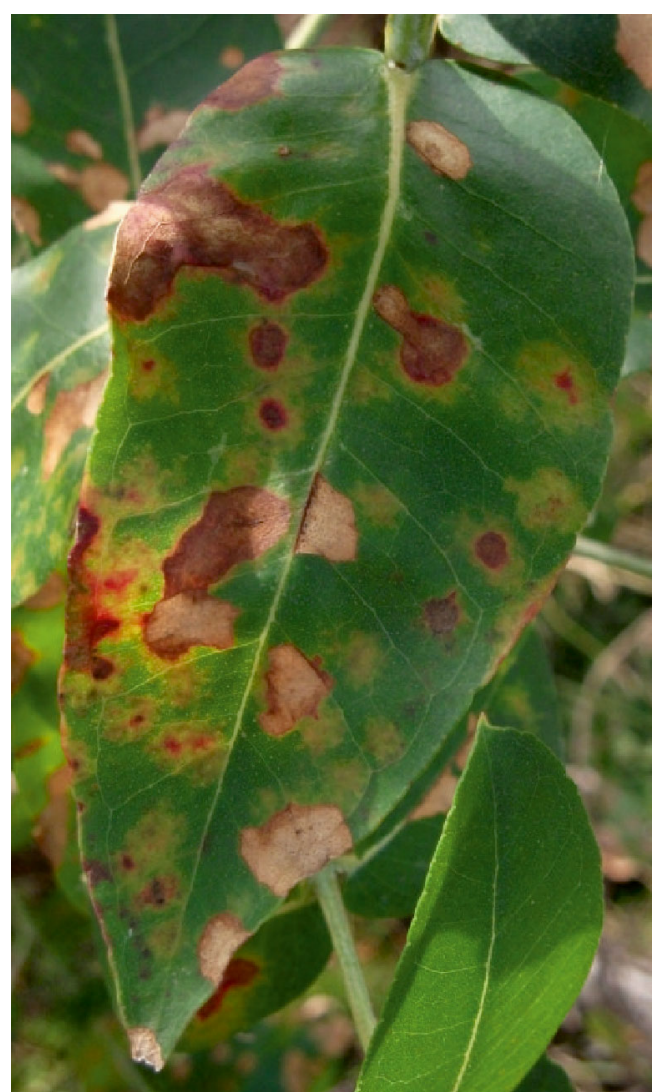

Fig. 1 Leaf spots of Teratosphaeria pseudoeucalypti on Eucalyptus globulus

maintened in the Facultad de Ingeniería fungal culture collection (FI). The microscopic characterization of pycnidia and conidia was performed. Conidia produced in culture were curved and hyaline, with 1-2 septa, (26.0) 28.0 ( 32.5) $\mu \mathrm{m} \times(2.0)-2.6-(2.8) \mu \mathrm{m}$. The cultural and micromorphological characteristics were similar to those of $T$. eucalypti, except by the hyaline conidia (Fig. 2).

Genomic DNA was extracted from fungal mycelia as described by Lee and Taylor (1990).

Partial DNA amplification of the beta-tubulin region $(\beta \mathrm{T})$ and elongation factor 1 -alpha $(\mathrm{EF}-1 \alpha)$ were performed. Primers used in each amplification were T1 and Bt2b (Glass and Donaldson 1995; O'Donnell and Cigelnik 1997), and EF1-728 and EF1-968 F (Carbone and Kohn 1999) respectively. The complete amplification of the internal transcribed spacer region (ITS-2) with primers ITS-3 and ITS-4 (White et al. 1990) was also performed. PCR conditions for each primers pair were as described by the authors. PCR products were purified and sequenced by Macrogen Korea (Seoul, Korea).

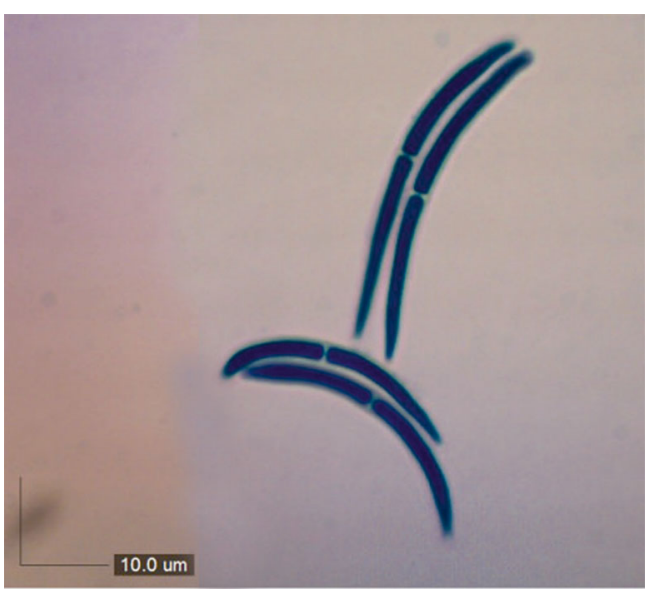

Fig. 2 Conidia morphology of Teratosphaeria pseudoeucalypti strain FI2292 in vivo, cotton blue stained. Bar $10 \mu \mathrm{m}$

Sequences obtained were manually corrected using Mega version 5.1 (Tamura et al. 2011) and aligned with reference sequences from the GenBank using Clustal W (Thompson et al. 1994). All sequences derived in this study were deposited in GenBank and accession numbers are shown in Table 1. Phylogenetical analysis of a combined data set sequence of the three genes ( $\beta \mathrm{T}$, EF$1 \alpha$ and ITS-2) was carried out with PAUP v4.0b10 (Swofford 2003) using the method of Maximun Parsimony (TreeBase 16019).

All characters were unordered and of equal weight. Gaps were treated as missing data. Bootstrap support values were calculated from 1,000 heuristic search replicates. The congruence of a combined dataset sequence of the three genes ( $\beta$ T, EF- $1 \alpha$ and ITS-2) was tested. Partition homogeneity test had been performed in PAUP v4.0b10 (Swofford 2003).

The combined $\beta$ T, EF $1-\alpha$ and ITS- 2 data set of the Teratosphaeria isolates included 657 nucleotides of which 84 were parsimony informative. The partition homogeneity test showed not significant differences $(P=0.39)$ between data from the different gene regions. The parsimony analysis showed that the six Uruguayan isolates were grouped in a well supported clade with Teratosphaeria pseudoeucalypti sequences with a bootstrap support of $98 \%$ (Fig. 3).

This study confirmed the presence for the first time of $T$. pseudoeucalypti outside Australia and the susceptibility of other species of Eucalyptus to this pathogen. The presence of this pathogen in Uruguay shows a wide range of dispersion of T. pseudoeucalypti. This constitutes a potential risk in temperate regions where forestry is mainly based on Eucalyptus spp. 


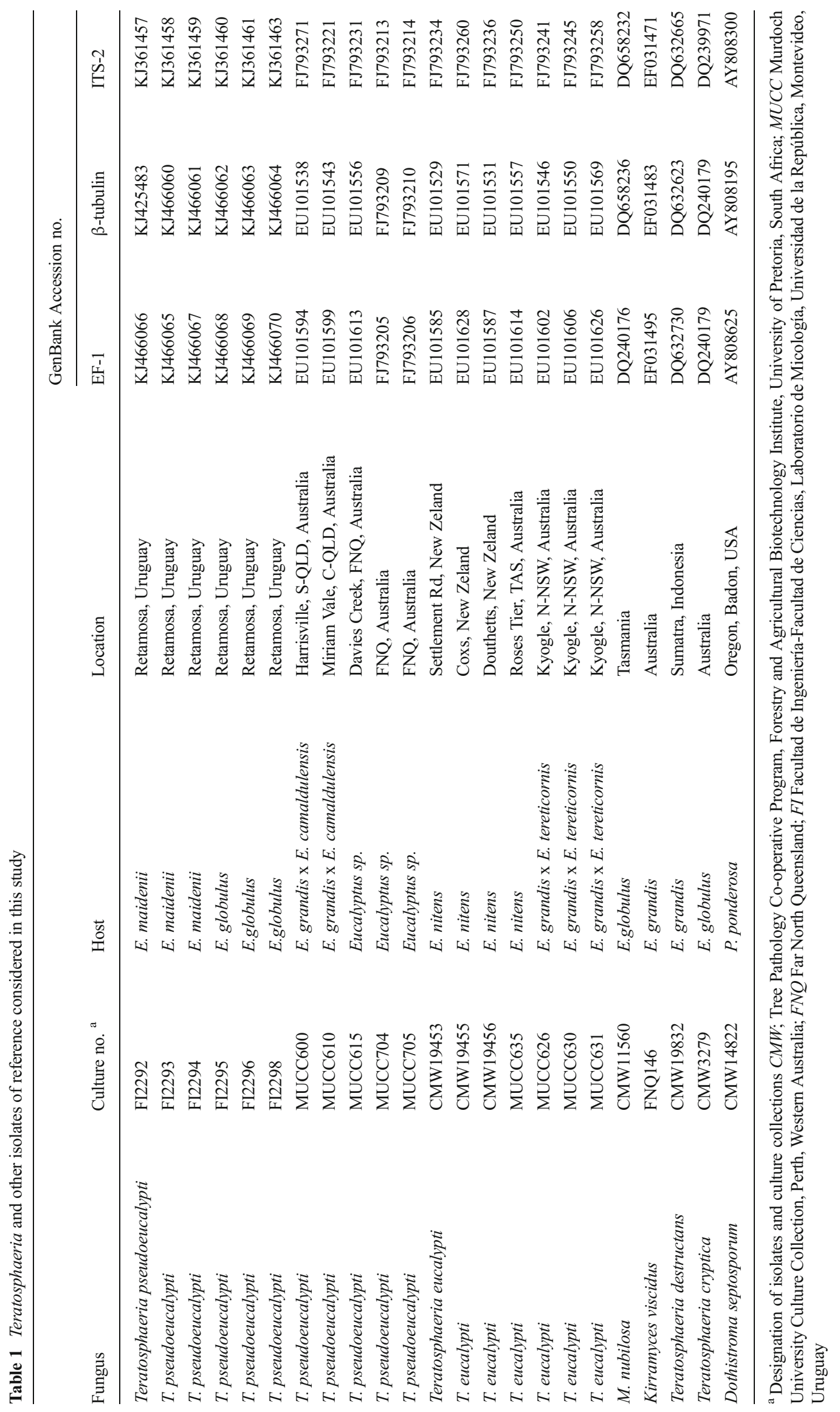


Fig. 3 Consensus tree obtained from heuristic search of the combined $\beta$-tubulin, EF $1-\alpha$ and ITS-2 sequences (TL: 508; CI: 0.9508; RI: 0.8649; RC: 0.8223). Bootstrap support values above $60 \%$ are shown above the nodes. Dothistroma septosporum was used as outgroup taxon. Isolates in bold print are from this study

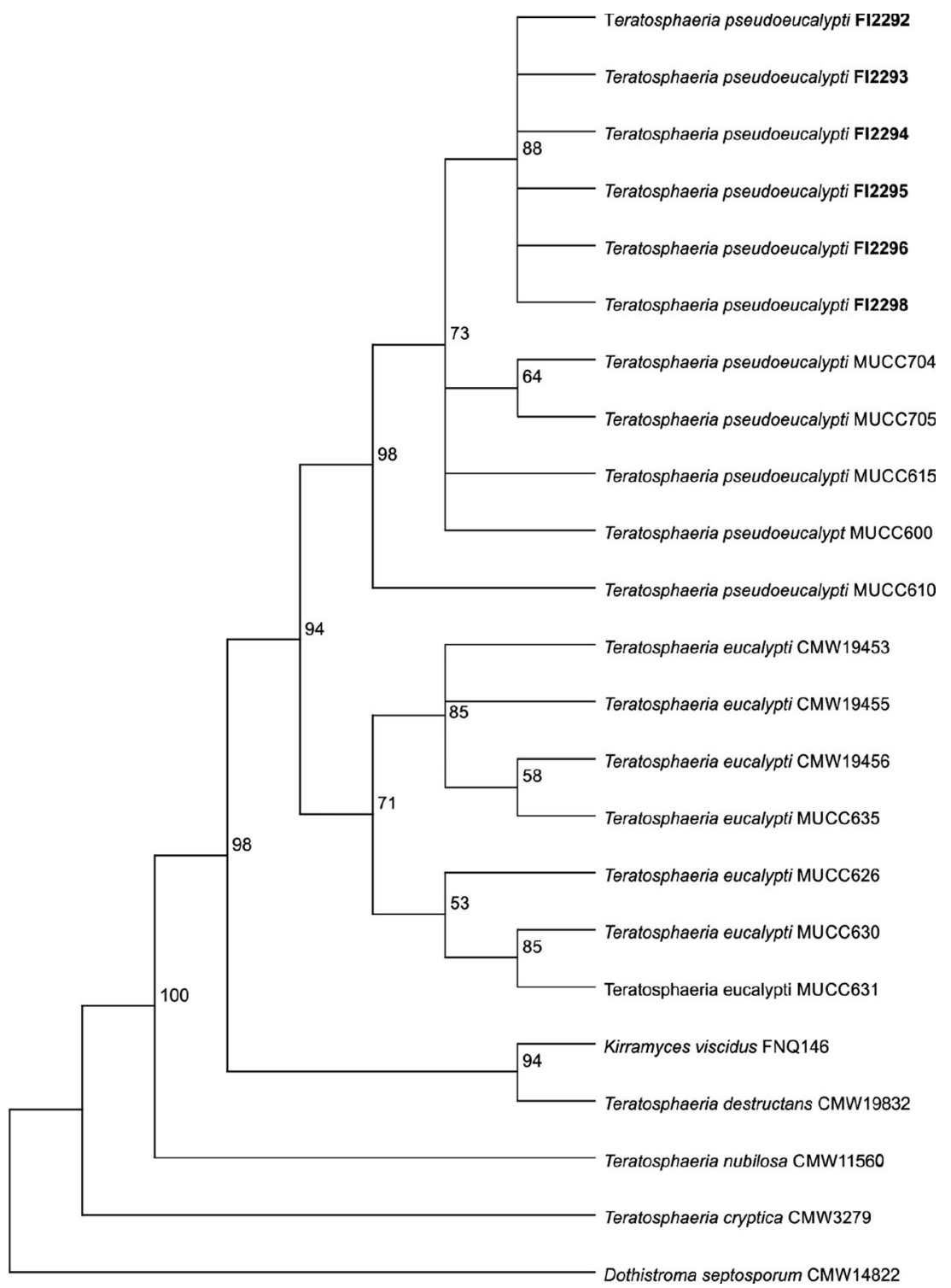

Acknowledgments We thanks to the Sociedad de Productores Forestales and to the Comisión Sectorial de Investigación Científica from Uruguay for the financial support. We also thanks Dr. Eduardo Abreo for the critical review of the manuscript.

\section{References}

Andjic V, Pegg GS, Carnegie AJ, Callister A, StJ Hardy GE, Burgess TI (2010) Teratosphaeria pseudoeucalypti, new cryptic species responsible for leaf blight of Eucalyptus in subtropical and tropical Australia. Plant Path 59:900-912

Carbone I, Kohn LM (1999) A method for designing primer sets for speciation studies in filamentous ascomycetes. Mycologia 91:553556
Glass NL, Donaldson GC (1995) Development of primers sets designed for use with the PCR to amplify conserved genes from filamentous ascomycetes. Appl Environ Microbiol 61: $1323-1330$

Lee S, Taylor J (1990) Isolation of DNA from fungal mycelia and single spores. In: Innis MA, Gelfand DH, Snindky JJ, White TJ (eds) PCR protocols: a guide to methods and applications. Academic, New York, pp 282-287

Lupo S, Navarrete F, Alonso R, Carrau D, Bettucci L (2008) Mycosphaerella species on Eucalyptus spp. plantations in Uruguay. VI Congreso Latinoamericano de Micología: libro de resúmenes, ALM 1a ed. Buenos Aires pp 253

O'Donnell K, E C (1997) Two different intragenomics rDNA ITS2 types within a monophyletic lineage of the fungus Fusarium are nonorthologous. Mol Phylogenet Evol 7:103-116

Pérez G, Hunter GC, Slippers B, Pérez C, Wingfield BD, Wingfield MJ (2009) Teratosphaeria (Mycosphaerella) nubilosa, the causal agent 
of Mycosphaerella leaf disease (MLD), recently introduced into Uruguay. Eur J Plant Pathol 125:109-118

MGAP (Ministerio de Ganadería Agricultura y Pesca) (2013) http://www.mgap.gub.uy/portal/hgxpp001.aspx? 7,20,441,O,S,0,MNU;E;134;2;MNU, Accesed 28 November 2013

Swofford DL (2003) PAUP* Phylogenetic analysis using parsimony (*and other methods). Version 4.0 sinauer associates, Sunderland, MA

Tamura K, Peterson D, Peterson N, Stecher G, Nei M, Kumar S (2011) Mega:5 Molecular evolutionary genetics analysis using maximum likelihood, evolutionary distance, and maximum parsimony methods. Mol Biol Evol 28:2731-2739

Thompson JD, Higgins DG, Gibson TJ (1994) CLUSTAL W: improving the sensitivity of progressive multiple sequence alignment through sequence weighting, position-specific gap penalties and weight matrix choice. Nucleic Acids Res 22:4673-4680

White TJ, Bruns T, Lee S, Taylor J (1990) Amplification and direct sequencing of fungal ribosomal RNA genes for phylogenetics. In: Innis MA, Gelfand DH, Snindky JJ, White TJ (eds) JO. Academic, New York, pp 315-322 